\title{
Prevalence and etiology of buffalo mastitis and milk somatic cell count in dry and rainy seasons in a buffalo herd from Analândia, São Paulo State, Brazil
}

[Prevalência e etiologia da mastite bubalina e contagem de células somáticas no leite, nas estações seca e chuvosa, em um rebanho bubalino do município de Analândia, Estado de São Paulo, Brasil]

\author{
L.J.L. Pizauro ${ }^{1}$, D.G. Silva ${ }^{1}$, A.M. Santana ${ }^{1}$, V. Clemente $^{2}$, G.H.B. Lara $^{3}$, F.J.P. Listoni ${ }^{4}$, \\ A.C.N. Vaz $^{5}$, A.M.C. Vidal-Martins ${ }^{5}$, M.G. Ribeiro ${ }^{4}$, J.J. Fagliari ${ }^{6}$ \\ ${ }^{1}$ Aluno de pós-graduação - FCAV-Unesp - Jaboticabal, SP \\ ${ }^{2}$ Médica veterinária autônoma \\ ${ }^{3}$ Aluno de pós-graduação - FMVZ-Unesp - Botucatu, SP \\ ${ }^{4}$ FMVZ-Unesp - Botucatu, SP \\ ${ }^{5}$ FZEA-USP - Pirassununga, SP \\ ${ }^{6}$ FCAV-Unesp - Jaboticabal, SP
}

\begin{abstract}
The aim of this study was to evaluate somatic cell count (SCC), prevalence and etiology of mastitis in a dairy buffalo herd from Analândia, São Paulo State, Brazil, in the dry and rainy seasons. Additionally, antimicrobial susceptibility profile of microorganisms isolated from milk samples was also evaluated. 1,042 milk samples from female Murrah buffaloes in a dairy farm located in Analândia, São Paulo State, Brazil, collected between May 2011 and November 2012 were analyzed. After the mammary gland physical examination, strip cup test and California Mastitis Test (CMT) were performed. Afterwards, $50 \mathrm{~mL}$ of milk samples from each mammary quarter were collected aseptically for SCC in automatic equipment and microbiological examination. The antimicrobial sensitivity profile to ampicillin, cefoperazone, ceftiofur, enrofloxacin, gentamicin, neomycin, oxacillin, penicillin, and sulfamethoxazole/trimethoprim was evaluated by disk diffusion method. The monthly average temperature and pluviometric index were obtained from "Centro Integrado de Informações Agrometeorológicas" (CIIAGRO) of "Instituto Agronômico de Campinas" (IAC). Milk samples with positive results in the microbiological test showed average SCC of 137,720 cells/mL in the dry period and 190,309 cells/mL in the rainy period. Although a higher number of isolated microorganisms was observed in buffalo milk samples during the rainy period (69/600) compared to the dry period (50/442), the season had no significant effect on the frequency of isolation of microorganisms. The main genera of microorganisms isolated were coagulase-negative Staphylococcus (38.4\%), Streptococcus agalactiae (28.8\%), and Bacillus spp. (7.56\%) during the dry season and Corynebacterium sp. (23.5\%), Streptococcus spp. (32.3\%), and Streptococcus agalactiae (9.24\%) during the rainy period. Multidrug resistance was observed in $30.1 \%$ of the isolated microorganisms.
\end{abstract}

Keywords: antibiogram, Bubalus bubalis, SCC, mammary gland, microorganisms

\section{RESUMO}

O objetivo do presente estudo foi avaliar a contagem de células somáticas, a prevalência e a etiologia da mastite bubalina nas estações seca e chuvosa em um rebanho de bubalinos do município de Analândia, estado de São Paulo, Brasil. Adicionalmente, verificou-se o perfil de sensibilidade antimicrobiana dos micro-organismos isolados nas amostras de leite das búfalas. Foram avaliadas 1.042 amostras de leite de búfalas da raça Murrah pertencentes a uma propriedade rural localizada no município de AnalândiaSP, obtidas no período de maio de 2011 e novembro de 2012. Após o exame físico da glândula mamária, foram realizados o teste da caneca de fundo escuro e o California Mastits Test (CMT); em seguida, foram

Recebido em 26 de setembro de 2013

Aceito em 10 de junho de 2014

E-mail: lucaspizauro@yahoo.com.br 
colhidas, de forma asséptica, amostras de 50mL de leite de cada quarto mamário, para a contagem de células somáticas (CCS) em aparelho automático e exame microbiológico. Também, foi avaliado o perfil de sensibilidade antimicrobiana a ampicilina, cefoperazona, ceftiofur, enrofloxacina, gentamicina, neomicina, oxacilina, penicilina e sulfametoxazol/trimetoprim, pelo método de difusão em disco. A temperatura média e o índice pluviométrico mensais foram obtidos no Centro Integrado de Informações Agrometeorológicas (CIIAGRO) do Instituto Agronômico de Campinas (IAC). Notou-se que as amostras de leite com resultado positivo no exame microbiológico apresentaram CCS média de 137.720 células/mL, no período seco, e 190.309 células/mL, no período chuvoso. Embora tenha se constatado maior índice de isolamentos de micro-organismos nas amostras de leite obtidas no período chuvoso (69/600) do que no período seco (50/442), a frequência de isolamentos não foi influenciada significativamente pela estação do ano. Os principais gêneros de micro-organismos isolados durante o período seco foram Staphylococcus coagulase negativa $(38,4 \%)$, Streptococcus agalactiae $(28,8 \%) e$ Bacillus spp. (7,56\%), e no período chuvoso Corynebacterium sp. (23,5\%), Streptococcus spp. (32,3\%) e Streptococcus agalactiae $(9,24 \%)$. Verificou-se resistência a três ou mais antimicrobianos em $30,1 \%$ dos micro-organismos isolados.

Palavras-chave: antibiograma, Bubalus bubalis, CCS, glândula mamária, micro-organismos

\section{INTRODUCTION}

The Brazilian buffalo herd in 2011 was 1.3 million animals and São Paulo State had the sixth largest herd of the country with 75,700 buffaloes (5.9\%) (Instituto..., 2012). The Brazilian production of buffalo milk and its derivatives has been growing annually, particularly in Southeast region, due to the appreciation of the physicochemical characteristics of buffalo milk (Madella-Oliveira et al., 2005).

The buffaloes, as well as bovines, may present mastitis, resulting in decreased milk production, changes in concentration of milk components and increase in somatic cell count (SCC), which varies according to the intensity and length of inflammation (Hamza and Choudhuri, 1994). Similarly to cows, the most frequently isolated bacteria in buffaloes mastitis are Staphylococcus and Streptococcus genera (Bastos and Birgel, 2011; Medeiros et al., 2011; Silva et al., 2011), however, the habit of buffaloes to enter marshes can favor mammary infection by environmental microorganisms, particularly fungi, algae and enterobacteria (Osman et al., 2009).

Studies also report seasonal influence in isolation of microorganisms which cause mastitis in cows in Brazil (Ferreira et al., 2006; Zafalon et al., 2008) and buffaloes in Turkey (Özenç et al., 2008; Gürler et al., 2013).

The aim of this study was to evaluate SCC, prevalence and etiology of mastitis in dairy buffaloes in dry and rainy seasons in a herd raised in Analândia, São Paulo State, Brazil. Additionally, the antimicrobial susceptibility profile of microorganisms isolated from milk samples was evaluated.

\section{MATERIAL AND METHODS}

1,042 milk samples from primiparous and pluriparous female Murrah buffaloes, submitted to mechanic milking once a day, from a rural property located in Analândia, São Paulo State, Brazil, collected from May 2011 to November 2012 were evaluated.

After the mammary gland physical examination (Radostitis et al., 2007), the milk from each mammary quarter was submitted to the strip cup test and California Mastitis Test (CMT) (Schalm and Noorlander, 1957). For somatic cell count (SCC) and microbiological test, $50 \mathrm{~mL}$ of milk samples of each mammary quarter were collected aseptically in sterilized plastic bottles with and without bronopol, respectively. SCC was obtained in automatic equipment (Somacount 300) by flow cytometry utilizing bovine matrix stands according to International Daily Federation (International..., 2006). Microbiological test was performed with standard techniques of NMC protocols (Laboratory..., 1999) by streaking 10uL of each milk sample in 5\% sheep blood agar and MacConkey agar, maintained at $37^{\circ} \mathrm{C}$ in aerobic conditions, with daily readings for 72 hours. Simultaneously, all milk samples were cultured on Sabouraud agar with dextrose and maintained at $37^{\circ} \mathrm{C}$ to isolate and identify fungi. The 
microorganisms were identified according to morpho-tinctorial, biochemical and culture characteristics (Quinn et al., 2011). Additionally, the antimicrobial sensitivity profile to ampicillin $(10 \mu \mathrm{g})$, cefoperazone (75 $\mu \mathrm{g})$, ceftiofur $(30 \mu \mathrm{g})$,

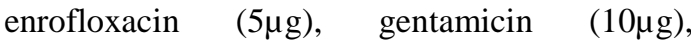
neomycin $(30 \mu \mathrm{g})$, oxacillin $(5 \mu \mathrm{g})$, penicillin (10IU) and sulfamethoxazole/trimethoprim (25 $\mu \mathrm{g})$ was evaluated by the disk diffusion method (Clinical..., 2006).

The monthly average temperature and pluviometric index were obtained from "Centro Integrado de Informações Agrometeorológicas” (CIIAGRO) of "Instituto Agronômico de Campinas” (IAC). As an adaptation from Zafalon et al., (2010) the months of the year were classified as "dry" (average rainfall of approximately $30 \mathrm{~mm}$ and maximum $<60 \mathrm{~mm}$ ) and "rainy" (average rainfall of approximately $120 \mathrm{~mm}$ and minimum $>70 \mathrm{~mm}$ ).

The average temperatures and rainfall values in dry and rainy periods were submitted to analysis of variance (ANOVA) and Student $t$ test to compare pairs of means $(\mathrm{P}<0.05)$. To assess the influence of dry and rainy periods in mastitis occurrence the chi-square test was used. To evaluate SCC obtained both in dry and rainy periods, the nonparametric Kruskal-Wallis test followed by Dunn's posttest comparison were used (Triola, 2008).

The study was approved by the Ethics Committee on Animal Use (Comissão de Ética no Uso de Animais - CEUA) of Faculdade de Ciências Agrárias e Veterinárias FCAV/UNESP/Jaboticabal Campus (Protocol No. 017093/12).

\section{RESULTS AND DISCUSSION}

According to the pluviometric index in the region of Analândia-SP during the study period, seven months were classified as dry and 12 months as rainy. The lowest rainfall $(0.1 \mathrm{~mm})$ was observed in July 2011, while the highest (266.1mm) was in January 2012. The lowest monthly minimum temperature $\left(1.5^{\circ} \mathrm{C}\right)$ was registered in June 2011 and the highest monthly maximum temperature $\left(30.9^{\circ} \mathrm{C}\right)$ was registered in October 2012 (Table 1).

A significant difference $(\mathrm{P}<0.05)$ was observed both for average temperature and rainfall in dry and rainy seasons (Table 2 ).

Table 1. Meteorological data from Analândia-SP region and monthly classification in dry and rainy, from May 2011 to November 2012

\begin{tabular}{lccccc} 
Month/year & $\begin{array}{c}\text { Minimum } \\
\text { temperature } \\
\left({ }^{\circ} \mathrm{C}\right)^{*}\end{array}$ & $\begin{array}{c}\text { Maximum } \\
\text { temperature } \\
\left({ }^{\circ} \mathrm{C}\right)^{*}\end{array}$ & $\begin{array}{c}\text { Average } \\
\text { temperature } \\
\left({ }^{\circ} \mathrm{C}\right)^{*}\end{array}$ & $\begin{array}{c}\text { Rainfall } \\
(\mathrm{mm})^{*}\end{array}$ & Classification \\
\hline May/2011 & 8.0 & 24.7 & 13.4 & 5.5 & Dry \\
June/2011 & 1.5 & 24.0 & 11.3 & 42 & Dry \\
July/2011 & 6.2 & 25.7 & 13.5 & 0.1 & Dry \\
August/2011 & 3.6 & 27.7 & 15.0 & 11.6 & Dry \\
September/2011 & 8.1 & 29.5 & 15.0 & 13.0 & Dry \\
October/2011 & 12.1 & 27.9 & 17.3 & 141.4 & Rainy \\
November/2011 & 10.9 & 28.1 & 16.4 & 142.2 & Rainy \\
December/2011 & 13.6 & 28.9 & 17.9 & 221.1 & Rainy \\
January/2012 & 15.1 & 27.0 & 18.0 & 266.1 & Rainy \\
February/2012 & 18.0 & 30.5 & 19.6 & 97.7 & Rainy \\
March/2012 & 15.0 & 29.2 & 18.4 & 79.3 & Rainy \\
April/2012 & 14.8 & 27.9 & 17.9 & 147.5 & Rainy \\
May/2012 & 10.0 & 23.9 & 13.8 & 103.1 & Rainy \\
June/2012 & 11.2 & 23.2 & 14.5 & 190.3 & Rainy \\
July/2012 & 5.2 & 24.5 & 12.4 & 42.7 & Dry \\
August/2012 & 9.3 & 26.2 & 14.1 & 2.4 & Dry \\
September/2012 & 7.4 & 28.9 & 15.2 & 77.4 & Rainy \\
October/2012 & 13.5 & 30.9 & 18.8 & 86.7 & Rainy \\
November/2012 & 13.5 & 28.9 & 17.7 & 130.1 & Rainy \\
\hline
\end{tabular}


Table 2. Average temperature and rainfall of Analândia-SP region, from May 2011 to November 2012, according to the time of the year (dry and rainy)

\begin{tabular}{ccc} 
Period & $\begin{array}{c}\text { Temperature } \\
\left({ }^{\circ} \mathrm{C}\right)\end{array}$ & $\begin{array}{c}\text { Rainfall } \\
(\mathrm{mm})\end{array}$ \\
\hline Dry & $19.8 \mathrm{~A}$ & $16.8 \mathrm{~A}$ \\
Rainy & $22.5 \mathrm{~B}$ & $140.2 \mathrm{~B}$ \\
\hline
\end{tabular}

Means in the same column followed by the same letter do not differ by Student $t$ test $(\mathrm{P}>0.05)$.
Regarding the CMT, of the 442 samples obtained in the dry period, $27(6.11 \%)$ had positive reactions and 415 (93.9\%) were negative to the test, while of the 600 samples collected during the rainy season, $60(10.0 \%)$ had positive results and $540(90.0 \%)$ were negative to the test (Table 3). During physical examination and strip cup test no changes were observed in mammary glands or in milk characteristics, respectively.

Table 3. Absolute and relative values of CMT from buffalo milk samples, from May 2011 to November 2012, in dry and rainy periods

\begin{tabular}{|c|c|c|c|c|c|}
\hline \multirow{2}{*}{ Period } & \multirow{2}{*}{ No. of samples } & \multicolumn{4}{|c|}{ CMT Result } \\
\hline & & - & + & ++ & +++ \\
\hline Dry & 442 & $\begin{array}{c}415 \\
(93.9 \%)\end{array}$ & $\begin{array}{c}11 \\
(2.49 \%)\end{array}$ & $\begin{array}{c}9 \\
(2.04 \%)\end{array}$ & $\begin{array}{c}7 \\
(1.58 \%)\end{array}$ \\
\hline Rainy & 600 & $\begin{array}{c}540 \\
(90.0 \%)\end{array}$ & $\begin{array}{c}17 \\
(2.83 \%)\end{array}$ & $\begin{array}{c}13 \\
(2.17 \%)\end{array}$ & $\begin{array}{c}30 \\
(5.00 \%)\end{array}$ \\
\hline Total & 1,042 & $\begin{array}{c}955 \\
(91.7 \%)\end{array}$ & $\begin{array}{c}28 \\
(2.69 \%)\end{array}$ & $\begin{array}{c}22 \\
(2.11 \%)\end{array}$ & $\begin{array}{c}37 \\
(3.55 \%)\end{array}$ \\
\hline
\end{tabular}

-: negative reaction; +: slight reaction; ++: moderate reaction; +++: intense reaction

According to Brito et al. (1997), positive reaction in CMT generally indicates inflammatory reaction in the mammary gland, suggesting subclinical mastitis. However, other factors of non-infectious origin, such as lactation stage, animal age and season, among others, may also influence CMT results, which is considered an indirect indicator of milk SCC, but the effects are minimal in uninfected mammary glands (Reneau, 1986; Harmon, 1994). Buffaloes are considered less susceptible to mastitis than cows, because of specific anatomical and physiological characteristics; several studies have reported low occurrence of clinical and subclinical mastitis in this species, in spite of the similarity of the etiologic agents in the two species (Jorge et al., 2005; Kapronezai et al., 2005; Carvalho et al., 2007; Sollecito et al., 2011).

Regardless of CMT results, all the 1,042 samples were submitted to the microbiological test and
119 (11.4\%) of them presented bacterial growth (Table 4). Although a greater number of isolated microorganisms was observed in milk samples obtained during the rainy period (69) than in dry one (50), the season had no significant influence on the frequency of isolation of microorganisms (Table 4). The greater number of isolations during the rainy period may be related to higher temperature and humidity (Table 2), which favors the proliferation of mastitis-causing microorganisms (Ferreira et al., 2006; Zafalon et al., 2008; Andrade et al., 2011). In addition, only $4.00 \%(2 / 50)$ and $13.0 \%(9 / 69)$ of milk samples with microbiological isolation in dry and rainy periods, respectively, showed slight to intense reaction in CMT, in accordance with the statement of Kapronezai et al. (2005) that there is high frequency of asymptomatic carriers in the herd or that CMT is not a good screening test for mastitis in buffaloes, due to the occurrence of false-positive and false-negative results.

Table 4. Absolute and relative values obtained in microbiological test from buffalo milk samples, from May 2011 to November 2012, in dry and rainy periods

\begin{tabular}{cccc}
\hline \multirow{2}{*}{ Period } & \multirow{2}{*}{ No. of samples } & \multicolumn{2}{c}{ Microbiological test result } \\
\cline { 3 - 4 } & & Negative & Positive \\
Dry & 442 & 392A (88.7\%) & 50A (11.3\%) \\
Rainy & 600 & 531A (88.5\%) & 69A (11.5\%) \\
\hline Total & 1.042 & $923(88.6 \%)$ & $119(11.4 \%)$ \\
\hline
\end{tabular}

Means in the same column followed by the same letter do not differ by chi-square test $(\mathrm{P}>0.05)$. 
The main isolated microorganisms during the dry period were coagulase-negative Staphylococcus (Staphylococcus spp.) (38.4\%), Streptococcus agalactiae (28.8\%) and Bacillus spp. (7.56\%) and in the rainy period were Corynebacterium sp. (23.5\%), Streptococcus spp. (32.3\%) and Streptococcus agalactiae (9.24\%) (Table 5). Other studies also reported Staphylococcus spp., Streptococcus spp., Corynebacterium sp. and Gram-negative bacteria as the most isolated etiologic agents from buffalo milk samples of different breeds (Bastos and Birgel, 2011; Medeiros et al., 2011; Silva et al., 2011). $\beta$-hemolytic streptococcus (Streptococcus agalactiae) are more pathogenic to domestic ruminants (Laboratory..., 1999; Quinn et al., 2011). The presence of hemolysis ( $\alpha$-hemolysis) should be considered an additional virulence factor, since hemolytic strains can release the iron ion from red blood cells; which is an essential element for bacterial growth (Laboratory..., 1999; Quinn et al., 2011).

Table 5. Absolute and relative values of isolated microorganisms, from May 2011 to November 2012, according to dry and rainy periods

\begin{tabular}{lccc}
\hline \multicolumn{1}{c}{ Microorganism } & \multicolumn{2}{c}{ Period } & \multirow{2}{*}{ Total } \\
\cline { 2 - 3 } Bacillus spp. & $9(7.56 \%)$ & $0(0.00 \%)$ & $9(7.56 \%)$ \\
Corynebacterium sp. & $0(0.00 \%)$ & $28(23.5 \%)$ & $28(23.5 \%)$ \\
Klebsiella pneumoniae & $1(0.84 \%)$ & $0(0.00 \%)$ & $1(0.84 \%)$ \\
Pasteurella multocida & $1(0.84 \%)$ & $0(0.00 \%)$ & $1(0.84 \%)$ \\
Staphylococcus aureus & $1(0.84 \%)$ & $0(0.00 \%)$ & $1(0.84 \%)$ \\
Staphylococcus spp. & $19(16.0 \%)$ & $5(4.20 \%$ & $24(20.2 \%)$ \\
Streptococcus agalactiae & $15(12.6 \%)$ & $11(9.24 \%)$ & $26(21.8 \%)$ \\
Streptococcus dysgalactiae & $2(1.68 \%)$ & $5(4.20 \%$ & $7(5.88 \%)$ \\
Streptococcus spp. & $0(0.00 \%)$ & $16(13.4 \%)$ & $16(13.4 \%)$ \\
Streptococcus $\alpha$-hemolytic & $1(0.84 \%)$ & $0(0.00 \%)$ & $1(1.68 \%)$ \\
Streptococcus $\beta$-hemolytic & $0(0.00 \%)$ & $2(1.68 \%)$ & $2(1.68 \%)$ \\
Staphylococcus spp + Staphylococcus $\beta$-hemolytic & $0(0.00 \%)$ & $1(0.84 \%)$ & $1(0.84 \%)$ \\
Staphylococcus spp + Streptococcus dysgalactiae & $1(0.84 \%)$ & $0(0.00 \%)$ & $1(0.84 \%)$ \\
Staphylococcus $\beta$-hemolytic + Streptococcus $\alpha$-hemolytic & $0(0.00 \%)$ & $1(0.84 \%)$ & $1(0.84 \%)$ \\
\hline Total & $50(42.0 \%)$ & $69(58.0 \%)$ & $119(100 \%)$ \\
\hline
\end{tabular}

Regarding the SCC, milk samples with negative results in microbiological test showed average values of 99,513 cells/mL and 125,606 cells/mL in dry and rainy periods, respectively. On the other hand, milk samples with positive results in microbiological test presented average values of 137,720 cells/mL and 190,309 cells/mL in dry and rainy seasons, respectively (Table 6). The variations in the SCC of milk samples with positive results in microbiological test collected during dry and rainy periods may be related to the stage of infection and the type of the isolated microorganism (Souza et al., 2009; Medeiros et al., 2011; Sollecito et al., 2011).

Table 6. Means and standard desviations of SCC of Murrah buffalo milk samples, according to the results of microbiological test and period of the year

\begin{tabular}{ccc}
\multirow{2}{*}{ Period } & \multicolumn{2}{c}{ SCC (cells/mL) } \\
\cline { 2 - 3 } & Negative & Positive \\
& microbiological test & microbiological test \\
\hline Dry & $99,513 \pm 243,887 \mathrm{Aa}$ & $137,720 \pm 623,118 \mathrm{Aa}$ \\
Rainy & $125,606 \pm 421,243 \mathrm{Aa}$ & $190,309 \pm 560,079 \mathrm{Ab}$ \\
\hline
\end{tabular}

Means in the same column followed by the same capital letters and same lower case letters in the same line do not differ by Dunn's test $(\mathrm{P}>0.05)$.

Regardless of the period of the year, the antibiogram results showed that $94.0 \%$ of the isolated bacteria were sensitive to gentamicin, $88.0 \%$ to ceftiofur, $88.0 \%$ to cefoperazone, $84.3 \%$ to ampicillin, $78.3 \%$ to oxacillin, $74.7 \%$ to penicillin, $71.1 \%$ to enrofloxacin, $67.5 \%$ to neomycin and $60.2 \%$ to sulfamethoxazole/trimethoprim (Figure 1). The 
same test indicated that $39.8 \%$ of the isolated bacteria were resistant to sulfamethoxazole/ trimethoprim, $32.5 \%$ to neomycin, $28.9 \%$ to enrofloxacin, $25.3 \%$ to penicillin, $21.7 \%$ to oxacillin, $15.7 \%$ to ampicillin, $12.0 \%$ to ceftiofur, $12.0 \%$ to cefoperazone and $6.00 \%$ to gentamicin (Figure 1). Multiresistance, defined as resistance to three or more types of antibiotics tested (Schwarz et al., 2010), was found in $30.1 \%$ of the isolated bacteria, of which $4.00 \%$ were resistant to three antibiotics, $16.0 \%$ to four antibiotics and $76.0 \%$ were resistant to five or more antibiotics, simultaneously. The high percentage of resistance to penicillin, neomycin and sulfamethoxazole/ trimethoprim and the presence of multidrug-resistant strains may be related to the indiscriminate use and dose, the range of application and duration of the antimicrobial use, allowing the selection of resistant strains, leading to a serious problem of public health.

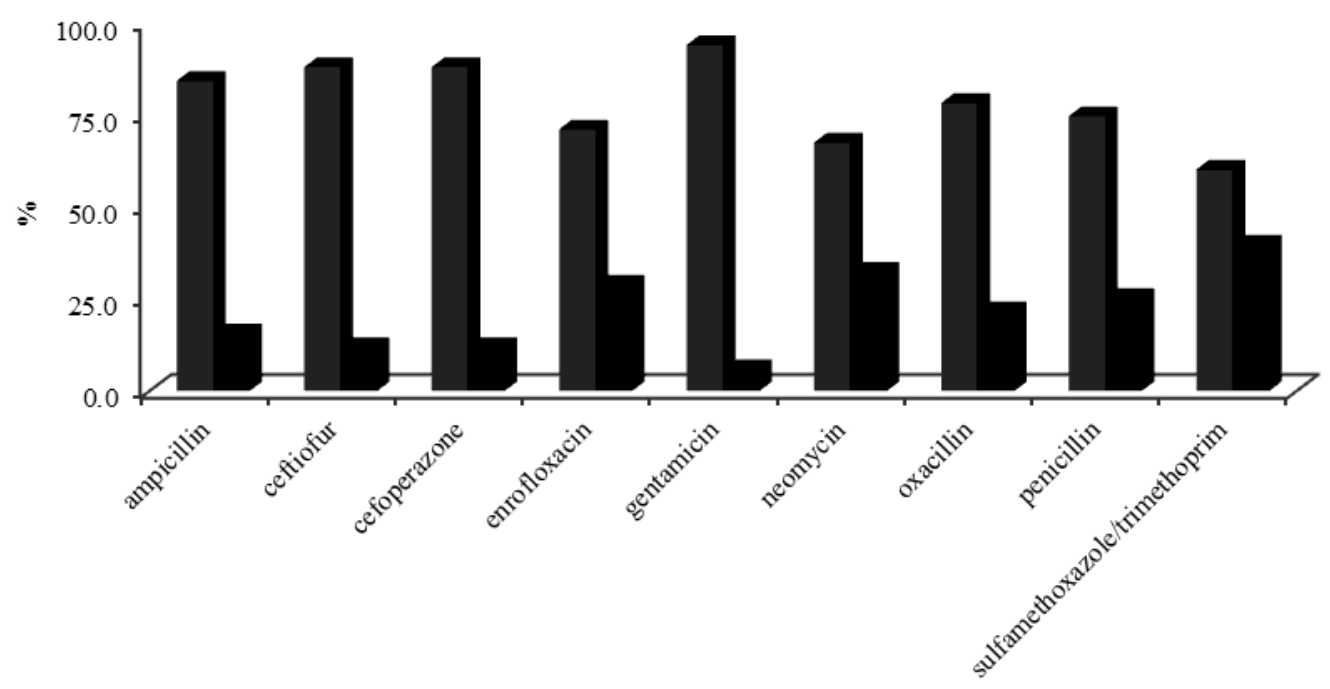

Antibiotics

\footnotetext{
- Sensitive Resistant
}

Figure 1. Antimicrobial sensitivity and resistance profiles of microorganisms isolated from Murrah buffalo milk samples.

\section{CONCLUSION}

Buffalo milk samples with positive result in microbiological test showed average SCC of 137,720 cells/mL in dry period and 190,309 cells $\mathrm{mL}$ in rainy period. No influence was observed regarding the dry and rainy seasons on the frequency of isolation of microorganisms. The main microorganisms isolated in the dry period were coagulase-negative Staphylococcus, Streptococcus agalactiae and Bacillus spp. and in the rainy period were Corynebacterium sp., Streptococcus spp. and Streptococcus agalactiae. Multidrug resistance to three or more drugs was observed in $30.1 \%$ of the isolated microorganisms.

\section{ACKNOWLEDGEMENTS}

The authors gratefully thank FAPESP for scholarship (Process No. 2011/03514-0) and financial support (Process No. 2011/19480-7).

\section{REFERENCES}

ANDRADE, K.D.; RANGEL, A.H.N.; ARAÚJO, V.M. et al. Efeito da estação do ano na qualidade do leite de búfalas. Rev. Verde Agroecol. Desenvol. Susten., v.6, p.33-37, 2011.

BASTOS, P.A.S.; BIRGEL, E.H. Leite de búfalas Murrah criadas em São Paulo (Brasil): influência da idade, fase de lactação, momento da ordenha e isolamento bacteriano na composição físico-química e celular. Rev. Educ. Contin. Med. Vet. Zootec., v.9, p.6-13, 2011. 
BRITO, J.R.F.; CALDEIRA, G.A.V.; VERNEQUE, R.S.; BRITO, M.A.V.P. Sensibilidade e especificidade do "California Mastitis Test" como recurso diagnóstico da mastite subclínica em relação à contagem de células somáticas. Pesq. Vet. Bras., v.17, p.49-53, 1997.

CARVALHO, L.B.; AMARAL, F.R.; BRITO, M.A.V.P. et al. Contagem de células somáticas e isolamento de agentes causadores de mastite em búfalas (Bubalus bubalis). Arq. Bras. Med. Vet. Zootec., v.59, p.242-245, 2007.

CLINICAL and laboratory standards institute. Performance Standards for Antimicrobial Disk Susceptibility Test (CLSI-NCCLS). 9.ed. Pennsylvania, 2006.

FERREIRA, L.M.; NADER FILHO, A.; OLIVEIRA, E. et al. Variabilidades fenotípica e genotípica de estirpes de Staphylococcus aureus isoladas em casos de mastite subclínica bovina. Cienc. Rural, v.36, p.1228-1234, 2006.

GÜRLER, Z.; KUYUCUOĞLU, Y., PAMUK, S. Chemical and microbiological quality of Anatolian buffalo milk. Afr. J. Microbiol. Res., v.7, p.1512-1517, 2013.

HAMZA, P.A.; CHOUDHURI, P.C. Chemoprophylactic studies on mastitis in buffaloes. Indian. J. Dairy. Sci., v.47, p.723-726, 1994.

HARMON, R.J. Physiology of mastitis and factors affecting somatic cell count. J. Dairy Sci., v.77, p.2103-2112, 1994.

INSTITUTO Brasileiro de Geografia e Estatística - IBGE. Produção da Pecuária Municipal - 2011, 2012. Disponível em: $<$ http://saladeimprensa.ibge.gov.br/noticias?view =noticia\&id=1\&busca=1\&idnoticia=2241>.

Acessado em: 18 out. 2012.

INTERNATIONAL Dairy Federation. Milk: enumeration of somatic cell. Part 2: Guidance on the operation of fluoro-opto-electronic counters. Brussels: IDF, 2006. 13p. (IDF Standard 148-2).

JORGE, A.M.; ANDRIGHETTO, C.; STRAZZA, M.R.B. et al. Correlação entre o California Mastitis Test (CMT) e a contagem de células somáticas (CCS) do leite de búfalas Murrah. Rev. Bras. Zootec., v.34, p.2039-2045, 2005.
KAPRONEZAI, J.; MELVILLE, P.A.; BENITES, N.R. Análise microbiológica, teste de Tamis e California Mastitis Test realizados em amostras de leite de fêmeas bubalinas pertencentes a rebanhos do Estado de São Paulo. Arq. Inst. Biol., v.72, p.179-83, 2005.

LABORATORY handbook on bovine mastitis. Madison, WI: National Mastitis Council, 1999. p.171-173.

MADELLA-OLIVEIRA, A.F.; QUIRINO, C.R.; ADONA, P.R.; PACHECO, A. Aspectos da comercialização de carne e leite de bubalinos na região Norte Fluminense. Rev. Bras. Rep. Anim., v.29, p.53-54, 2005.

MEDEIROS, E.S.; BARBOSA, S.B.P.; JATOBÁ, R.B. et al. Perfil da contagem de células somáticas na infecção intramamária em búfalas na Região Nordeste do Brasil. Pesq. Vet. Bras., v.31, p.219-223, 2011.

OSMAN, K.M.; EL-ENBAAWY, M.I.; EZZELDEEN, N.A.; HUSSEIN, H.M.G. Mastitis in dairy buffalo and cattle in Egypt due to Clostridium perfringens: prevalence, incidence, risk factors and costs. Rev. Sci. Tech. Oie., v.28, p.975-986, 2009.

ÖZENÇ, E.; VURAL, M.R.; ŞEKER, E.; UÇAR, M. An evaluation of subclinical mastitis during lactation in Anatolian buffaloes. Turk. J. Vet. Anim. Sci., v.32, p.359-368, 2008.

QUINN, P.J.; MARKEY, B.K.; LEONARD, F.C. et al. Veterinary Microbiology and Microbial Disease. 2.ed. UK: Wiley-Blackwell, 2011.

RADOSTITS, O.M.; GAY, C.C.; HINCHCLIFF, K.W.; CONSTABLE, P.D. Diseases of the mammary gland. In:__. (Eds.). Veterinary Medicine - A Textbook of the Diseases of Cattle, Horses, Sheep, Pigs, and Goats. 10.ed. Philadelphia: Saunders, 2007. cap.15, p.673-763.

RENEAU, J.K. Effective use of dairy herd improvement somatic cell counts in mastitis control. J. Dairy Sci., v.69, p.1708-1720, 1986.

SCHALM, O.W.; NOORLANDER, D.O. Experiments and observations leading to development of the California Mastitis Test. J. Am. Vet. Med. Assoc., v.130, p.199-204, 1957. 
SCHWARZ, S.; SILLEY, P.; SIMJEE, S. et al. Assessing the antimicrobial susceptibility of bacteria obtained from animals. J. Antimicrob. Chemother. v.65, p.601-604, 2010.

SILVA, D.G.; SANTANA, A.M.; PIZAURO, L.J.L. et al. Prevalência e etiologia da mastite subclínica em búfalas Jafarabadi. In: CONGRESSO BRASILEIRO DE MEDICINA VETERINÁRIA, 38., 2011, Florianópolis. Anais... Florianópolis: Sociedade Brasileira de Medicina Veterinária, 2011. R1203. (Resumo)

SOLLECITO, N.V.; LOPES, L.B.; LEITE R.C. Contagem de células somáticas, perfil de sensibilidade antimicrobiana e microrganismos isolados de mastites em búfalos: uma breve revisão. Rev. Bras. Med. Vet., v.33, p.18-22, 2011.
SOUZA, G.N.; BRITO, J.R.F.; MOREIRA, E.C. et al. Variação da contagem de células somáticas em vacas leiteiras de acordo com patógenos da mastite. Arq. Bras. Med. Vet. Zootec., v.61, p.1015-1020, 2009.

TRIOLA, M.F. Introdução à estatística. 10.ed. Rio de Janeiro: LTC, 2008. 696p.

ZAFALON, L.F.; ARCARO, J.R.P.; NADER FILHO, A.; VESCHI, J.L.A. Contagem de células somáticas no leite de vacas de diferentes raças em distintas lactações e condições climáticas. Vet. Zootec., v.17, p.378-385, 2010.

ZAFALON, L.F.; LANGONI, H.; BENVENUTTO, F. et al. Aspectos epidemiológicos da mastite bovina causada por Staphylococcus aureus. Vet. Zootec., v.15, p.56-65, 2008. 